\title{
Effect of Demographics, Attitudes and Learning Facilities on Management Accounting Performance
}

\author{
Radziah Mahmud $^{1}$, Nor Suhailati Abdul Manan ${ }^{1} \&$ Marshita Hashim ${ }^{1}$ \\ ${ }^{1}$ Faculty of Accountancy, Universiti Teknologi MARA, Malaysia \\ Correspondence: Radziah Mahmud, Faculty of Accountancy, Universiti Teknologi MARA, Malaysia.
}

Received: April 20, 2019

Accepted: May 7, 2019

Online Published: May 19, 2019

doi:10.5430/ijfr.v10n3p291

URL: https://doi.org/10.5430/ijfr.v10n3p291

\begin{abstract}
This study examines whether the students' demographics, attitudes and learning facilities influence the accounting students' performance in management accounting paper. Using questionnaire survey on 195 accounting students of a Malaysian public university, this study discovers that English proficiency, statistics, preparation for test or exam, study habits and learning facilities influence the performance of accounting students in management accounting. The findings in this study will create awareness among the students about their responsibilities to achieve better performance and assist the university in strategizing programs to enhance students' academic performance.
\end{abstract}

Keywords: demographic, attitudes, learning facilities, performance

\section{Introduction}

Academic performance is considered an important element in assessing the students' performance. It is a compulsory criterion that needs to be met when students are considering pursuing their studies or applying for jobs (Alos, Caranto \& David, 2015) besides equipped with good soft skills such as analytical, research and leadership skills. A great deal of consideration has been paid to empirical evidence on the possible determinants of academic performance covering various aspects.

The core courses in most undergraduate accounting programme are financial reporting, management accounting, finance, auditing, taxation, and corporate governance. Despites many researches done on accounting students' performance, there are limited number of studies carried out on cost accounting and management accounting courses. A few studies consider the students' performance in management accounting such as studies done by Raehsler, Hung, Yang, and Stuhldreher (2012) and Drennan and Rohde (2002). Studies on management accounting courses, specifically in Malaysia, are sparse. This study focuses on the factors affecting accounting students' academic performance particularly those enrolling in the first management accounting course in a Malaysian public university.

This study attempts to investigate the factors that may associate with the students' performance in Management Accounting and Control (MAC) paper specifically in a Malaysian public university. The MAC paper is an introduction paper useful for internal reporting or decision making. This paper is introduced to the second year undergraduate students, incorporating knowledge on standard costing and variance analysis, budgetary control, short term decision making, divisional performance as well as transfer pricing. The knowledge obtained from this paper will be beneficial in planning and making decision by providing detailed information on numerous aspects.

Learning management accounting courses is considered to be challenging due to unfamiliar terms and concepts (King \& McConnell, 2010; Krishna, et al. 2018). Unlike financial accounting, management accounting is focused on internal and operational report which does not have any specific standards to be complied with. The course considers both quantitative and qualitative information and students are anticipated to relate their knowledge to the real situation. In July 2017 examination, the results in the selected Malaysian public university reported a significantly higher failure rate that is about $36 \%$ of the total students who sat for the MAC paper. One of the faculty's key performance indicators states that there should be no paper with a failure rate of more than $25 \%$. This results in the faculty being unable to achieve one of its key performance indicators. Thus, this study is conducted to explore the factors that influence the students' performance in the MAC paper.

In anticipating students' performance in the MAC paper, results of studies across a broad range of education conclude that factors such as students' profiles, attitude and environment contribute significantly to academic performance. This 
paper extends the background literature exploring factors affecting students' success in MAC. This work builds on prior research on the effects of students' demographics, preparation, study habits, timely submission of projects and in addition considers how class size, the use of library, sufficiency of references and text books affect student performance in MAC.

The outcomes of this study may create awareness among students about their responsibilities to achieve better performance particularly in management accounting courses. The results of this study will also assist the university to strategize on enhancing of students' performance by changing the students' attitude towards learning and evaluation activities as well as providing conducive learning environment and facilities.

\section{Literature Review}

Academic performance of students is generally viewed as the product of socio-economic, psychological and environmental factors. Thus, the factors affecting academic performance are expected to differ from one country to another (Al-Mutairi, 2011). Magaji (2014) states characterisation of performance is the apparent demonstration of understanding, concepts, skills, ideas and knowledge of a person and proposes that grades clearly depict the performance of a student. Hence, their academic performance must be managed efficiently by viewing all the relevant factors that can affect their educational performance. There have been a large number of studies conducted in the past to identify the factors that contribute to academic performance, particularly among tertiary students (Alhajraf \& Alasfour, 2014; Mushtaq \& Khan, 2012; Al-Mutairi, 2011).

It is debated that students' prior knowledge and skills are essential when they learn more advanced courses (Kelly \& Glaspole, 2006; Kojo \& Paschal 2018 ) as prior knowledge is regarded as an important factor that influences the learning activities and consequently students' performance (Hailikari, Katajavuori \& Lindblom-Ylanne, 2008). Knowledge acquisition and high order cognitive problem-solving skills are dependent on the amount and quality of prior knowledge (Hailikari, Nevgi \& Lindblom-Ylanne, 2007). Drennan and Rohde (2002) discover that the success in the first managerial accounting course is seen to be related to better performance in second managerial accounting course.

The previous studies also indicate that the English language proficiency plays a vital role in ensuring students' performance particularly when the courses are taught in English. Harb and El-Shaarawi (2006) depict that the most imperative factor with positive effect on academic performance is the student's English language competency. They regard students with strong communication skills and have better grasp of the language have better performance compared to those who have less communication skills. It is possible to see communication as a variable which may be positively related to performance among students who engaged in open learning (Al-Mutairi, 2011; Khemili \& Belloumi 2018). Wongtrirat (2010) reported that proficiency in English has predictive ability on students' academic achievement. Another similar study on the significance of English proficiency in affecting academic excellence in English-based accounting program conducted by AlHaddad, Mohamed, \& AlHabshi (2004) is consistent with the results of the above mentioned studies. Drennan and Rohde (2002) also deliberate that proficiency in the English language do affect the performance, even though the variance is considered low.

Apart from English language proficiency, students' knowledge in Mathematics course is also significant in determining accounting students' performance (Magaji \& Umar, 2015; Khan \& Aslam 2017). It is proposed that knowledge in Mathematics course is crucial for accounting students since core courses for accounting are concerned with numerical measurements as well as operational concepts (Alhaji Haruna, 2011) which will enhance students' soft skills particularly in problem solving and critical thinking skills.

Students' attitude is also considered important in contributing towards students' performance. This includes students' preparedness for the classes and examination, prompt submission of assignments and regular revisions of the subject matters. Bratti and Staffolani (2002) suggest that more self-study time normally lead to a better performance in non-quantitative disciplines rather than quantitative disciplines. Jaravaza, Mabhungu and Nyengerai (2013) suggest that there is a strong association between success in basic accounting courses and students thoroughness in examination preparation, learning resources quality, use of technology and a conductive classroom environment. Janssen and O'Brien (2014) assert that attitudes and behaviours, such as procrastination and working with others directly affect homework score. However, the factors do not affect the examination results. They conclude that graded assignment is beneficial to learning, and attitudes and behaviours related to the assignments may have an indirect positive impact on exam performance.

Previous literature has also reported that students' performance relies on learning facilities available as well as the demographic characteristics such as gender and age differences. Mushtaq and Khan (2012) propose that the internal 
and the external classroom factors strongly affect the students' academic performance. The internal classroom factors consist of students' English language proficiency, teachers' teaching styles and roles, availability of resources and other learning facilities, assignments as well as the examination system. Environment and technological aspects of the classrooms are also part of the internal factors; whereas the factors such as extracurricular activities, financial, social and family problems are regarded as the external classroom factors. The study reveals that the learning facilities are imperative factors that affect students' performance.

\section{Research Methodology}

Accounting students of Bachelor in Accountancy from a Malaysian public university that took Management Accounting and Control (MAC) were chosen as the sample in this study. 195 students participated in this study. The MAC paper is the first management accounting paper offered at the Accountancy Bachelor programme. It emphasizes on the application of management accounting information and techniques to be used for planning, controlling and making decisions.

A questionnaire survey which is designed based on previous literature is used as the research instrument in this study. This approach is employed as it is considered to be an effective approach in analyzing large samples and it permits respondents to express their views without being influenced by others. The questionnaire is developed to obtain all information needed to achieve the objective of this study. The questionnaire consists of 3 sections, A, B and C. Section A is related to the respondents' demographic profile such as gender, entry requirement, English language proficiency, grade in Statistics and grade in Management Accounting and Control paper. The English language proficiency is measured by Malaysian University English Test (MUET) bands. Section B is related to the attitude of respondents. It covers the preparation for test or examination, study habits and the submission of projects or assignments given. Section $\mathrm{C}$ covers the learning facilities which include the classroom condition, the use of library, the sufficiency of references given and the relevancy of the recommended text book.

The questionnaire was distributed to accounting students in September 2017. A reliability coefficient of the instrument using Cronbach Alpha was 0.742. The data were analysed using SPSS.

\section{Results and Discussion}

\subsection{Demographic Profiles}

Based on Table 1, 25\% of the respondents were male whereas $75 \%$ were female. This scenario is common in Malaysia as more than $50 \%$ of accounting students are female which is consistent with Azis, Mahmud, Muda, Ismail, Abu Bakar and Saad (2017), Mahmud, Mohd Nasir, Abu, Sulaiman and Aziz (2015) and Hanafiah, Hussain and Mokhtar (2015). Out of 165 respondents, 66.2\% of them hold a Diploma in Accountancy. The balance did Malaysian Matriculation Program, a pre-university course that allows the students to pursue an accounting degree. This result indicates that the main feeder of the accounting students in the chosen university comes from the diploma programme which is in line with Azis et al. (2017) and Mahmud et al. (2015). The table shows that $73 \%$ of the respondents are modest users which mean that, even though they have quite a few grammatical errors, they are able to communicate fairly fluent with appropriate use of language. Since the respondents have a fair understanding of language and context, they do not have much problem in understanding the subject matter which is taught in English. They also have a fair ability to perform their tasks in English. Only 4\% of the respondents are proficient users suggesting that they have fluent, appropriate use of language and very minimal grammatical errors in terms of communication. Besides that, they have good understanding of language and context as well as have a high ability to perform their tasks in English.

Table 1. Demographic profile

\begin{tabular}{llllllll}
\hline & \multicolumn{2}{l}{ Gender } & \multicolumn{2}{l}{ Entry Requirement } & \multicolumn{2}{l}{ English Proficiency } \\
\hline & Male & Female & Diploma & Matriculation & $\begin{array}{l}\text { Modest } \\
\text { user }\end{array}$ & $\begin{array}{l}\text { Satisfactory } \\
\text { user }\end{array}$ & $\begin{array}{l}\text { Proficient } \\
\text { user }\end{array}$ \\
\hline Frequency & 48 & 147 & 129 & 66 & 143 & 44 & 8 \\
\hline$\%$ & 24.6 & 75.4 & 66.2 & 33.8 & 73.3 & 22.6 & 4.1 \\
\hline
\end{tabular}

The results in Table 2 indicate that while $34.8 \%$ of the respondents obtained $\mathrm{C}+$ and $\mathrm{C}$ in MAC, only $0.5 \%$ respondent obtained A-. In other words, nearly $35 \%$ of the respondents merely passed the course. On average, the 
grade in MAC is only $\mathrm{C}$ and $36 \%$ of the respondents failed the course. This is definitely quite alarming since this paper which has been offered to second year accounting students is regarded as at an introductory level and yet the failure rate is considered to be too high.

Table 2. Respondents' grade in MAC

\begin{tabular}{lllllllllll}
\hline Grade & A- & B+ & B & B- & C+ & C & C- & D+ & D & E \\
\hline Frequency & 1 & 9 & 21 & 26 & 34 & 34 & 14 & 23 & 21 & 12 \\
\hline$\%$ & 0.5 & 4.6 & 10.8 & 13.3 & 17.4 & 17.4 & 7.2 & 11.8 & 10.8 & 6.2 \\
\hline
\end{tabular}

The finding in Table 3 suggests that more than $85 \%$ obtained grade A in Statistics course, a branch of Mathematics. It can be said that the accounting students should have analytical thinking ability in solving the problem given as knowledge in mathematics should enhance students' intellectual, problem solving skills and ability to deliberate (Alhaji Haruna, 2011).

Table 3. Respondents' grade in statistics

\begin{tabular}{llllllll}
\hline Grade & A & A- & B+ & B & B- & C+ & C \\
\hline Frequency & 169 & 8 & 3 & 12 & 1 & 0 & 2 \\
\hline$\%$ & 86.7 & 5.1 & 1.5 & 6.2 & 0.5 & 0 & 1 \\
\hline
\end{tabular}

Using Chi square analysis, this study determines whether there is association between respondents' entry level, English language proficiency, performance in Statistics, attitudes and learning facilities with their performance in MAC.

\subsection{Demographic Factors and Performance}

Table 4. Demographic factors and performance

\begin{tabular}{|c|c|c|c|c|c|c|c|c|c|}
\hline & \multicolumn{3}{|c|}{ Entry Requirement } & \multicolumn{3}{|c|}{ English Proficiency } & \multicolumn{3}{|c|}{ Statistics } \\
\hline & Value & $\begin{array}{l}d \\
f\end{array}$ & $\begin{array}{l}\text { Asymp. } \\
\text { Sig. } \\
\text { (2-sided) }\end{array}$ & Value & $\begin{array}{l}d \\
f\end{array}$ & $\begin{array}{l}\text { Asymp. } \\
\text { Sig. } \\
\text { (2-sided) }\end{array}$ & Value & $\begin{array}{l}\mathrm{d} \\
\mathrm{f}\end{array}$ & $\begin{array}{l}\text { Asymp. } \\
\text { Sig. } \\
\text { (2-sided) }\end{array}$ \\
\hline Pearson Chi-Square & 1.089 & 1 & 0.297 & 7.796 & 2 & 0.020 & 8.430 & 2 & 0.015 \\
\hline Likelihood Ratio & 1.080 & 1 & 0.299 & 8.446 & 2 & 0.015 & 8.040 & 2 & 0.018 \\
\hline $\begin{array}{l}\text { Linear-by-Linear } \\
\text { Association }\end{array}$ & 1.083 & 1 & 0.298 & 4.270 & 1 & 0.039 & 6.673 & 1 & 0.010 \\
\hline $\mathrm{N}$ of Valid Cases & 195 & & & 195 & & & 195 & & \\
\hline
\end{tabular}

Results in Table 4 posit that there is no difference between diploma students and matriculation students in terms of prior knowledge in management accounting. Although students from diploma program sit for 3 management accounting papers as compared to only 1 paper for students from matriculation program, it seems that prior knowledge is not associated with the performance in MAC. Thus, this finding is inconsistent with Rhoda, Muhammad Imran, Mohd, Mahzan, and Asif (2011), and Seery (2009). It could be due to sequencing effects (Bower, 2002; Khan, et al. 2016) where students from diploma program have a gap between the last management accounting papers at diploma level and the MAC. Consistent with previous studies (Mahmud et al., 2015), this study finds that English proficiency has association with respondents' performance. It is suggested that being proficient in English assists students to understand and be able to apply the management accounting information and techniques for planning, control and decision making which leads to better performance in MAC. The result also suggests that good performance in Statistics (one of Mathematics courses) has association with students' performance. This finding is 
supported by Shaban (2015), Raehsler et al. (2012) and Mumuni, Acquah and Anti Partey (2010). It is proposed that a good mathematical background will assist students in understanding the accounting concepts better that those without good background.

\subsection{Attitude and Performance}

It is expected that students who have positive attitudes towards learning activities are found to exhibit better academic achievement (Awang, Jindal-Snape\& Barber, 2013). In this study, students' attitudes in terms of preparation for the test or final examination, study habits and timely submission of projects or assignments were examined. This result supports the view that preparation and regular studying have association with performance in MAC as indicated in Table 5. Thus, it proves the general view that students who prepare early and revise often usually obtain better results and it is consistent with previous studies such as Sibanda, Iwu, and Benedict (2015), Alos et al. (2015), Awang et al. (2013), and Mohd, Mahmood \& Ismail (2011).

Table 5. Attitude and performance

\begin{tabular}{|c|c|c|c|c|c|c|c|c|c|}
\hline & \multicolumn{3}{|c|}{ Preparation } & \multicolumn{3}{|c|}{ Study Habit } & \multicolumn{3}{|c|}{ On time Submission } \\
\hline & Value & $\begin{array}{l}\mathrm{d} \\
\mathrm{f}\end{array}$ & $\begin{array}{l}\text { Asymp. Sig. } \\
\text { (2-sided) }\end{array}$ & Value & df & $\begin{array}{l}\text { Asymp. Sig. } \\
\text { (2-sided) }\end{array}$ & Value & $\begin{array}{l}\mathrm{d} \\
\mathrm{f}\end{array}$ & $\begin{array}{l}\text { Asymp. Sig. } \\
\text { (2-sided) }\end{array}$ \\
\hline $\begin{array}{l}\text { Pearson } \\
\text { Chi-Square }\end{array}$ & 4.200 & 1 & 0.040 & 3.497 & 1 & 0.061 & 1.254 & 1 & 0.263 \\
\hline Likelihood Ratio & 4.036 & 1 & 0.045 & 3.455 & 1 & 0.063 & 1.188 & 1 & 0.276 \\
\hline $\begin{array}{l}\text { Linear-by-Linear } \\
\text { Association }\end{array}$ & 4.178 & 1 & 0.041 & 3.479 & 1 & 0.062 & 1.247 & 1 & 0.264 \\
\hline $\mathrm{N}$ of Valid Cases & 195 & & & 195 & & & 195 & & \\
\hline
\end{tabular}

With regards to timely submission of projects or assignment, Table 5 exhibits that there is no association between this attribute with students' performance in MAC. This indicates that students' performance is not affected on whether the projects or assignments are submitted on time. The content of the projects or assignment is more important than the timing of the submission.

\subsection{Learning Facilities and Performance}

Table 6a. Learning facilities and performance

\begin{tabular}{lllllll}
\hline & \multicolumn{2}{l}{ Classroom } & \multicolumn{3}{l}{ Use of Library } \\
\hline & Value & df & $\begin{array}{l}\text { Asymp. Sig. } \\
(2 \text {-sided })\end{array}$ & Value & df & $\begin{array}{l}\text { Asymp. Sig. } \\
\text { (2-sided) }\end{array}$ \\
\hline Pearson Chi-Square & 10.233 & 1 & 0.001 & 10.233 & 1 & 0.001 \\
\hline Likelihood Ratio & 11.176 & 1 & 0.001 & 11.176 & 1 & 0.001 \\
\hline Linear-by-Linear Association & 10.181 & 1 & 0.001 & 10.181 & 1 & 0.001 \\
\hline N of Valid Cases & 195 & & & 195 & & \\
\hline
\end{tabular}

Previous literature such as Yahaya, Yahaya and Idris (2012) and Harb and El-Shaawari (2006) suggest that comfortable learning environment will induce positive attitude and consequently it will lead to better performance. Table 6a shows that classroom condition has association with performance and this result supports the findings in Frimpong, Agyeman and Ofosu (2016) and Heinesen (2010) where overcrowded classroom has adverse impact on performance. In the similar vein with Gbemi-Ogunleye (2016), Mushtaq and Khan (2012) and Gaona and Gonzalez (2011), this study proposes that the use of library has association with performance in MAC. Even though online resources are available, it does not reduce students' dependency on resources in the library. The library does not only 
provide reading materials, it also provides facilities such as wifi, learning and discussion areas, training, computer labs, seminar room, discussion room as well as research writing room.

Table $6 \mathrm{~b}$. Learning facilities and performance

\begin{tabular}{lllllll}
\hline & \multicolumn{3}{l}{ Sufficiency of References } & \multicolumn{2}{l}{ Relevancy of Text Book } \\
\hline & Value & df & $\begin{array}{l}\text { Asymp. Sig. } \\
\text { (2-sided) }\end{array}$ & Value & df & $\begin{array}{l}\text { Asymp. Sig. } \\
\text { (2-sided) }\end{array}$ \\
\hline Pearson Chi-Square & 5.557 & 1 & 0.018 & 10.989 & 1 & 0.001 \\
\hline Likelihood Ratio & 5.468 & 1 & 0.019 & 10.793 & 1 & 0.001 \\
\hline Linear-by-Linear Association & 5.528 & 1 & 0.019 & 10.933 & 1 & 0.001 \\
\hline N of Valid Cases & 195 & & & 195 & & \\
\hline
\end{tabular}

Table $6 \mathrm{~b}$ posits that sufficient references have association with performance in the MAC and this is consistent with Enu and Nkum (2015). This finding supports the argument that sufficient references will enhance the students' performance as proper references are essential in the effective teaching and learning process. Lots of new and recent information can be gathered from different management accounting references. Availability of relevant textbook is considered to be another contributing factor that influences the students' performance in MAC (Frimpong, et al, 2016; Kanwal, Kha \& Baloch 2017). This finding supports the view that relevant textbook has association with performance since good textbook is considered as excellent teaching aids for students in providing a balanced, chronological presentation of concepts and principles in the MAC.

\section{Conclusion}

This study infers that English language proficiency, performance in Statistics, preparation for test or examination, study habit and learning facilities have association with academic achievement in the MAC paper. On the other hand, prior knowledge and timely submission of projects or assignments are not associated with good performance in the MAC paper. There are several limitations pertaining to this study. This study is only focused on demographic factors, attitude and learning facilities. There are other factors such as lecturers' contribution, learning style and the use of ICT on learning process that are not considered in this study Hence, the generalizability of the findings may be limited. This study should include samples from other public universities to provide more vigorous findings. The outcomes of this study will create consciousness among the students regarding their responsibilities to attain better academic performance and assist the university in planning activities to enhance students' performance.

\section{References}

AlHaddad, S. K., Mohamed, M., \& AlHabshi, S. M. (2004). An exploratory study on English language proficiency in the context of globalization of accounting education. Journal of Financial Reporting and Accounting, 2(1), 73-87. https://doi.org/10.1108/19852510480000661

Alhaji Haruna, J. (2011). Relationship between entry grades in mathematics and students performance in financial accounting in federal colleges of education in Nigeria. Dissertation, Ahmadu Bello University Zaria, Nigeria.

Alhajraf, N. M., \& Alasfour, A. M. (2014). The impact of demographic and academic characteristics on academic performance. International Business Research, 7(4), 92-100. https://doi.org/10.5539/ibr.v7n4p92

Al-Mutairi, A. (2011). Factors Affecting business students' performance in Arab Open University: The case of Kuwait. International Journal of Business and Management, 6(5), 146-155. https://doi.org/10.5539/ijbm.v6n5p146

Alos, S. B., Caranto, L. C., \& David, J. J. T. (2015). Factors affecting the academic performance of the student nurses of BSU. International Journal of Nursing Science, 5(2), 60-65.

Awang, M. M., Jindal-Snape, D., \& Barber, T. (2013). A documentary analysis of the government's circulars on positive behaviour enhancement strategies. Asian Social Science, 9(5), 203-208. https://doi.org/10.5539/ass.v9n5p203

Azis, N., Mahmud, R., Muda, R., Ismail, A. H., Abu Bakar, Y., \& Saad, S. (2017). Performance in financial reporting course using framework-based teaching of Malaysian Financial Reporting Standards. Advanced Science Letters, 
23(10), 9363-10480. https://doi.org/10.1166/asl.2017.9528

Bower, N. W. (2002). Development of a simple mathematic predictor of student performance in general chemistry. The Journal of Scholarship of Teaching and Learning, 3(1), 4-13.

Bratti, M., \& Staffolani, S. (2002). Student time allocation and educational production functions. Working Paper No. 170, University of Ancona Department of Economics. https://doi.org/10.2139/ssrn.321020

Drennan, L., \& Rohde, F. H. (2002). Determinants of performance in advanced undergraduate management accounting: An empirical investigation. Accounting and Finance, 42, 27-40. https://doi.org/10.1111/1467-629X.00065

Enu, J. A. O. K., \& Nkum, D. (2015). Factors influencing students' mathematics performance in some selected colleges of education in Ghana. International Journal of Education Learning and Development, 3(3), 68-74.

Frimpong, E. A, Agyeman, G. A., \& Ofosu, F. F. (2016). Institutional factors affecting the academic performance of polytechnic students in Ghana. International Journal of Humanities \& Social Science Studies, 2(5), 102-109.

Gaona, J. C. G., \& Gonzalez, E. R. V. (2011). Relationship between reading habits, university library and academic performance in a sample of psycology students. Revista de la Educacion Superior, XL(1), No. 157, 55-73.

Gbemi-Ogunleye, P. (2016). Library use and students academic achievement: Implication for counseling. Information and Knowledge Management, 6(2), 50-52.

Hailikari, T., Katajavuori, N., \& Lindblom-Ylanne, S. (2008). The relevance of prior knowledge in learning and instructional design. American Journal of Pharmaceutical Education, 72(5), 1-8. https://doi.org/10.5688/aj7205113

Hailikari, T., Nevgi, A., \& Lindblom-Ylanne, S. (2007). Exploring alternative ways of assessing prior knowledge, its components and their relation to student achievement: A mathematical-based case study. Studies in Educational Evaluation, 33, 320-337. https://doi.org/10.1016/j.stueduc.2007.07.007

Hanafiah, M. H., Hussain, M. N. \& Mokhtar, A. A. (2015). The influence of gender, ethnicity and academic performance on Islamic business course. Jurnal Personalia Pelajar, 18(1), 123-132.

Harb, N., \& El-Shaarawi, A. (2006). Factors affecting students' performance. Munich personal Repec Archive paper No. 13621. 17.

Heinesen, E. (2010). Estimating class-size effects using within school variation in subject specific classes: An important interaction. Advances in Health Sciences Education, 5(3), 197-205.

Janssen, S., \& O'Brien, M. (2014). Disentangling the effects of student attitudes and behaviors on academic performance. International Journal for the Scholarship of Teaching and Learning, 8(2). https://doi.org/10.20429/ijsotl.2014.080207

Jaravaza, D. C., Mabhungu, I., \& Nyengerai, S. (2013). Student's perspective on factors influencing academic performance in introductory accounting courses at universities in Zimbabwe. International Journal of Innovative Research and Development, 2(6), 286-293.

Kanwal, R., Khan, F. R., \& Baloch, S. M. (2017). Comparative Study of Linguistic Features in Gender Communication in Pakistani Television Talk Show. International Journal of English Language and Literature Studies, 6(2), 54-62. https://doi.org/10.18488/journal.23.2017.62.54.62

Kelly, N., \& Glaspole, S. E. (2006). Formative assessment as a learning aid for pharmacy calculations - a theory based design. Pharmacy Education, 6(1), 27-31. https://doi.org/10.1080/15602210500528059

Khan, N., Ali, K., Kiran, A., Mubeen, R., Khan, Z., \& Ali, N. (2016). Factors that affect the derivatives usage of non-financial listed firms of Pakistan to hedge foreign exchange exposure. Journal of Banking and Financial Dynamics, 1(1), 9-20. https://doi.org/10.20448/journal.525/2017.1.1/525.1.9.20

Khan, R. E. A., \& Aslam, I. (2017). Child immunization in Pakistan: Socio-institutional and regional aspects. Asian Journal of Economic Modelling, 5(1), 49-56. https://doi.org/10.18488/journal.8/2017.5.1/8.1.49.56

Khemili, H., \& Belloumi, M. (2018). Cointegration Relationship between Growth, Inequality and Poverty in Tunisia. International Journal of Applied Economics, Finance and Accounting, 2(1), 8-18. https://doi.org/10.33094/8.2017.2018.21.8.18

King, G. H., \& McConnell, C. (2010). Using a common experience to teach introductory managerial accounting. 
Journal of Instructional Pedagogies, 4, 1-8.

Kojo, R., \& Paschal, N. (2018). Urban Population Growth and Environmental Sustainability in Nigeria. Journal of Empirical Studies, 5(1), 12-19. https://doi.org/10.18488/journal.66.2018.51.12.19

Krishna, M., Mei, C. Y., Cing, C. W., Yin, L. M., Hui, L. X., Sheng, S. Y., \& Lin, T. W. (2018). Internet Abuse Intention at Workplace among Employees: A Malaysian Perspective. Humanities and Social Sciences Letters, 6(4), 156-170. https://doi.org/10.18488/journal.73.2018.64.156.170

Magaji, Z. B. (2014). Influence of social networking usage on business education students academic performance in federal universities in Nigeria.

Magaji, Z. B., \& Umar, R. T. (2015). Effect of mathematics and English language proficiency on academic performance of business education students in financial accounting. Journal of Sceince, Technology \& Education, 3(1), 68-67.

Mahmud, R., Mohd Nasir, N., Abu, A., Sulaiman, N., \& Aziz@Omar, Z. (2015). Factors that contribute to the high failure rate of the introductory financial accounting and reporting paper at the undergraduate level: The case of Universiti Teknologi MARA. ASEAN Conference on Accounting Education (ACAE) 2015.

Mohd, N., Mahmood, T. F. P. T., \& Ismail, M. N. (2011). Factors that influence students in mathematics achievement. International Journal of Academic Research, 3(3), 49-54.

Mumuni, B. Y., Acquah, B. Y. S., \& Anti Partey, P. (2010). The relationship between students' achievements in mathematics and their performance in economics. International Journal of Educational Leadership, 3(3), 320-330.

Mushtaq, I., \& Khan, S. N. (2012). Factors affecting students' academic performance. Global Journal of Management and Business Research, 12(9), 17-22.

Raehsler, R. D., Hung, K., Yang, C. W., \& Stuhldreher, T. J. (2012). Are mathematics, economics and accounting courses important determinants in financial management: A rank order approach. Journal of Economics and Finance Education, 11(1), 48-59.

Rhoda D. B., Muhammad Imran, Y., Mohd. Mahzan, A., \& Asif, N. R. (2011). The effect of prior knowledge in understanding chemistry concepts by senior secondary school students. International Journal of Academic Research, 3(2), 607-611.

Seery, M. K. (2009). The role of prior knowledge and student aptitude in undergraduate performance in chemistry: a correlation-prediction study. Chemistry Education Research and Practice, 10, 227-232. https://doi.org/10.1039/b914502h

Shaban, O. (2015). The relationship between mathematics grades and the academic performance of the accounting students' department. The European Proceedings of Social \& Behavioural Sciences, 4(1), 85-91. https://doi.org/10.15405/epsbs.2015.05.6

Sibanda, L., Iwu, C. G., \& Benedict, O. H. (2015). Factors influencing academic performance of university students. Demography and Social Economy, 2(24), 103-115. https://doi.org/10.15407/dse2015.02.103

Wongtrirat, R. (2010). English language proficiency and academic achievement of international students: A meta-analysis. Doctoral dissertation.

Yahaya, A., Yahaya, N., \& Idris, F. (2012). Aggressive behaviour and the influence factors at five schools in Johor Bahru. Elixir Psychology, 42A, 6530-6536. 